\title{
PREFÁCIO À ILÍADA DE HOMERO, TRADUZIDA EM ROMENO POR CH. I. SULIOTIS $^{1}$
}

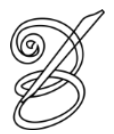 \\ Traduzido por: \\ Ana Alethea de Melo Cesar OSÓRIO* \\ Universidade de Brasília \\ Brasília, Distrito Federal, Brasil \\ Anne PODA** \\ Universidade do Oeste de Timisoara \\ Timișoara, Timiș, Romania
}

RECEBIDO EM: 10 de novembro de 2019

ACEITO EM: 30 de novembro de 2019

PUBLICADO EM: abril 2020

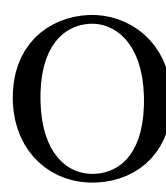

gênio de Homero influenciou enormemente a literatura antiga e moderna. Os gênios literários que nascem no seio de uma nação lhe prestam um grande serviço, mas também sobrevivem por milhares de anos, transgredindo as fronteiras da nação de origem e tornando-se gênios universalmente conhecidos.

Além disso, através das suas canções, Homero, o poeta da Ilíada, imortalizou o gênio da Grécia antiga e, ao mesmo tempo, legou um legado imperecível pelo qual temos uma admiração sem limites. Da mesma forma, ele inspirou os grandes poetas pela simplicidade narrativa dos fatos; as imagens que apresenta de maneira tão vívida que mesmo o leitor mais impaciente não pode abandonar a leitura da Ilíada ou da Odisseia, uma vez que a tenha começado. No entanto, a beleza de uma obra literária é de difícil acesso numa língua morta há tantos séculos.

Para que a sublimidade de obras como a de Homero seja compreendida pela consciência dos leitores que ignoram o grego antigo, os modernos sentiram a necessidade de traduzir a Ilíada e a Odisseia para a sua própria língua.

Então, da minha parte, tomei coragem e comecei a traduzir as obras de Homero para romeno numa língua [alvo - N.T.] que eu valorizo e muito próxima da língua do texto original, e que corresponde ao gênio da língua romena. 
Sei muito bem que esta é uma tarefa bastante difícil para mim e que, para realizá-la, seria necessário ter penado muito mais no domínio da literatura romena.

Também estou convencido de que não vou produzir uma tradução perfeita. No entanto, o leitor benevolente e assíduo notará, disto estou certo, as dificuldades que um tradutor enfrenta quando deseja traduzir com fidelidade, e também evitar sacrificar a pureza e a naturalidade da língua da tradução em nome da fidelidade à língua traduzida.

A satisfação moral me tranquilizará, porque, por meio desta tradução, terei prestado ao menos um pequeno serviço à nossa literatura [romena], que se empenhou resolutamente no caminho do progresso, ao que me parece.

Dito isto, apresento ao leitor a tradução do primeiro livro de uma obra admirada pelos leitores durante séculos. Para louvar Homero, peço emprestado ao gênio de um poeta francês estas palavras:

"Três mil anos se passaram sobre as cinzas de Homero

E, depois de três mil anos, Homero respeitado

É jovem ainda de glória e de imortalidade" (CHÉNIER, 1826, p. 21, tradução nossa)

148 Creio que esta tradução poderia ser utilizada para a formação de jovens que estudam grego antigo e, para que a leitura possa atingir o seu objetivo, é desejável que se leiam as explicações, indispensáveis para o estudo de qualquer obra clássica.

Consequentemente, coloquei abaixo das palavras as suas formas mais difíceis, uma tarefa que qualquer edição cuidadosa exige, e indiquei as formas gramaticais de cada uma das palavras que expliquei de forma tão sucinta quanto possível na língua romena. Além disso, na medida do possível, tenho trabalhado em uma breve nota sobre os costumes e a religião dos antigos gregos que facilitam a compreensão do texto.

Para isso, utilizei as obras dos melhores exegetas de Homero, em particular os comentários e dicionários alemães.

Se as razões que me motivaram a iniciar este empreendimento estavam certas e, em particular, se o resultado for um sucesso, caberá aos críticos benevolentes provar se estamos certos ou errados.

I.S. Spartali 


\footnotetext{
1 Tradução do texto:

Homer, Iliada : Cartea I- $a$; tradusă şi adnotată în limba română de Christodul I. Suliotis. Brăila, Typ. Siloghi, 1876. BCU Iași, Cota LSIII-4.733.
}

* Ana Alethea de Melo Cesar OSÓRIO - Bacharel em Letras - Tradução/Inglês (2011) pela Universidade de Brasília. Especialista em Revisão de Textos (2015) pelo Centro Universitário de Brasília. Mestranda em Estudos da Tradução na Universidade de Brasília. Revisora de textos na Editora Universidade de Brasília. Universidade de Brasília, Instituto de Letras, Programa de Pós-Graduação em Estudos da Tradução. Brasília, Distrito Federal, Brasil.

Currículo acadêmico: http://lattes.cnpq.br/5685363692393264

ORCID: https://orcid.org/0000-0002-2101-9566

E-mail: anaalethea@gmail.com

** Anne PODA - Tradutora independente de textos gerais, científicos e literários. Participou da equipe de tradução do livro Le Nom propre en traduction de Michel Ballard, feita pelos membtos do grupo de pesquisa nISTTRAROM-Translationes e coordenado por G. Lungu-Badea. Universidade do Oeste de Timisoara, Timisoara, Timis, Romênia.

ORCID: https://orcid.org/0000-0003-2292-9710

Courriel : annepoda@gmail.com 